\title{
ANALISIS PENGELOLAAN ALOKASI DANA DESA TERHADAP PERCEPATAN PEMBANGUNAN KAMPUNG AMUMA DISTRIK AMUMA KABUPATEN YAHUKIMO
}

\author{
MARLIN SEKENIL* dan ELIUS HELUKA** \\ *Mahasiswa Prodi Akuntansi, Universitas Ottow Geissler \\ **Dosen Prodi Manajemen, Sekolah Tinggi Ilmu Ekonomi Port Numbay
}

\begin{abstract}
The Village Fund Allocation (ADD) is part of village finances obtained from regional tax revenue sharing and part of the central and regional financial balance funds received by districts/cities for villages which are distributed proportionally. This study aims to determine how much the management of village fund allocations, the management of village fund allocations and what factors affect the management of village fund allocations to accelerate the development of Amuma Village, Amuma District, Yahukimo Regency. The data used in this study are primary data and secondary data with research subjects consisting of the village government, village consultative bodies, village community empowerment institutions and the Amuma village community, Amuma District, Yahukimo Regency. The results of the study show that the management of village fund allocations in increasing the acceleration of village development, where there are three stages, namely planning, implementation and accountability. From the planning stage, it can be seen from the musrembang held by the village head that the implementation of the allocation of village funds is still less effective, where in the musrembang activity community participation is still very low, due to the lack of transparency from the village head to the community. The implementation stage is still not effective, where the use of the village fund allocation budget can be resolved individually due to the lack of transparency of the village head to the community, at the accountability stage in the process it is still not good. The management of village fund allocations is still insufficient, where the preparation of accountability reports is not prepared by the village head and there is no evaluation of activities that should be carried out with the Amuma village community. This is because the process created in each stage of the management of the allocation of village funds is not in accordance with the management principles and objectives of the allocation of village funds which prioritizes transparency of information to the community as an evaluation team of every development activity carried out. Meanwhile, the inhibiting factors are the lack of human resources from the management implementation team, information, and the lack of community participation.
\end{abstract}

Keywords: Management of Fund Allocation \& Acceleration of Village Development

\begin{abstract}
Abstrak: Alokasi Dana Desa (ADD) merupakan bagian keuangan desa yang diperoleh dari bagi hasil pajak daerah dan bagian dari dana perimbangan keuangan pusat dan daerah yang diterima oleh kabupaten/kota untuk desa yang dibagikan secara proporsional. Penelitian ini bertujuan untuk mengetahui berapa besar pengelolaan alokasi dana desa, pengelolaan alokasi dana desa dan faktor apa saja mempengaruhi pengelolaan alokasi dana desa terhadap percepatan pembangunan kampung amuma distrik amuma Kabupaten Yahukimo. Data yang digunakan dalam penelitian ini adalah data primer dan data sekunder dengan subjek penelitian yang terdiri dari pemerintah desa, badan permusyawaratan desa lembaga pemberdayaan masyarakat desa dan masyarakat kampung amuma Distrik Amuma Kabupaten Yahukimo. Hasil penelitian menunjukan bahwa besar pengelolaan alokasi dana desa dalam meningkatkan percepatan pembangunan kampung, dimana ada tiga tahap yakni perencanaan, pelaksanaan dan pertanggungjawaban. Dari tahapan perencanaan, dilihat dari musrembang yang diadakan kepala desa pelaksanaan alokasi dana desa masih kurang efektif, dimana dalam kegiatan musrembang partisipasi masyarakat masih sangat rendah, dikarenakan kurangnya transparansi dari kepala kampung kepada masyarakat. Tahapan pelaksanaan masih kurang baik efektif, dimana penggunaan anggaran alokasi dana desa dapat terselesaikan terindividu dikarenakan kurangnya transparansi kepala kampung kepada masyarakat, pada tahapan pertanggungjawaban dalam proses masih belum kurang baik. Pengelolaan alokasi dana desa masih kurang cukup, dimana penyusunan laporan pertanggungjawaban tidak disususn oleh kepala kampung dan tidak adanya evaluasi kegiatan yang seharusnya dilakukan bersama masyarakat desa amuma. Hal ini karena proses yang tercipta dalam setiap tahapan pengelolaan alokasi dana desa tersebut belum sesuai dengan prinsip pengelolaan dan tujuan alokasi dana desa yang mengutamakan transparansi informasi kepada masyarakat sebagai tim evaluasi dari setiap kegiatan pembangunan yang dilakukan. Sedangkan faktor-faktor penghambat adalah sumber daya manusia yang kurang dari tim pelaksana pengelolaan, informasi, serta kurangnya partisipasi masyarkat.
\end{abstract}

Kata kunci: Pengelolaan Alokasi Dana \& Percepatan Pembangunan Kampung

\section{Pendahuluan}

Berdasarkan peraturan kementerian desa, pembangunan daerah tertinggal, dan transmigrasi Nomor 5 tahun 2015 tentang penetapan prioritas penggunaan dana desa, dana desa di tahun 2015-2019 ini digunakan untuk membiayai pelaksanaan program dan kegiatan berskala lokal desa bidang pembangunan desa dan pemberdayaan masyarakat desa. Prioritas pertama penggunaan dana desa ada beberapa bidang prioritas utama yaitu; bidang membangun infrastuktur jalan, irigasi, jembatan sederhana, dan talud. Bidang kesehatan dan pendidikan juga perlu diprioritaskan, yakni Posyandu, Paud, TK dan Sekolah Dasar.

Peraturan Pemerintah (PP) nomor 8 tahun 2016 tentang perubahan kedua atas PP Nomor 60 tahun 2014 tentang dana desa yang bersumber dari anggaran pendapatan dan belanja negara (APBN). Anggaran Pendapatan dan Belanja Negara (APBN) dalam pemantapan dan pengembangan kapasitas untuk 
meningkatkan kapasitas kepala desa, perangkat desa, anggota badan permusyawaratan desa agar lebih mampu menyelenggarakan pelayanan kepada masyarakat secara demokratis, transparan dan akuntabel berdasarkan nilainilai sosial budaya setempat.

Menurut peraturan Pemerintah RI Nomor 72 tahun 2005 tentang desa sebagaimana dimaksud pada ayat (2) bahwa perencanaan pembangunan desa disusun secara partisipatif oleh pemerintahan desa sesuai dengan kewenangannya dan menurut ayat (3) bahwa dalam menyusun perencanaan pembangunan desa wajib melibatkan lembaga kemasyarakatan desa. Tujuan perencanaan pembangunan adalah untuk; 1) Mengkoordinasikan antar pelaku pembangunan; 2) Menjamin sinkronisasi dan sinergi dengan pelaksanaan pembangunan daerah; 3) Menjamin keterkaitan dan konsistensi antara perencanaan, penganggaran, pelaksanaan dan pengawasan; 4) Mengoptimalkan partisipasi masyarakat; 5) Menjamin tercapainya penggunaan sumber daya desa secara efisien, efektif, berkeadilan dan berkelanjutan.

Dengan berlakunya Undang-Undang Nomor 9 tahun 2015 tentang pemerintah daerah, dan pemerintah daerah menjalakan otonomi seluas-luasnya. Menurut H.A.W.Widjaja, (2007:37) menyatakan bahwa Otonomi berhak mengatur dan mengurus rumah tangga sendiri dengan memperhatikan khususan dan keragaman daerah melalui peningkatan daya saing setiap daerah dengan memperhatikan prinsip demokrasi, pemerataan keadilan sehingga dalam diarahkan untuk percepatan pembangunan guna meningkatkan kesejahteraan masyarakat.

Berdasaran kewenangan yang dimiliki daerah maka penyelenggaraan otonomi daerah memerlukan pembiayaan yang ditanggung oleh daerah melalui keuangan daerah. Menurut Badrudin Rudy, (2012:13) menyatakan faktor keuangan merupakan faktor yang mempengaruhi tingkat kemampuan daerah dalam melaksanakan otonomi, keuangan inilah merupakan dalam satu dasar kriteria untuk mengetahui secara nyata kemampuan daerah dalam mengurus rumah tangganya sendiri. Dalam melaksakan keuangan daerah perlu dibuatkan suatu rencanaan agar seluruh kegiatan yang akan dilaksanakan dapat dikelola dengan baik. Bentuk perencanaan keuangan daerah inilah yang dikenal dengan istilah Anggaran Pendapatan dan Belanja Daerah (APBD), dan bagian dari pendapatan daerah adalah dana desa.

Alokasi dana yang merata dan tepat sasaran serta pengelolaan sumber-sumber pendapatan secara optimal, efisien dan efektifitas dalam penggunaan anggaran belanja merupakan hal pokok yang harus selalu diperioritaskan. Alokasi Dana Desa (ADD) merupakan bagian keuangan desa yang diperoleh dari bagi hasil pajak daerah dan bagian dari dana perimbangan keuangan pusat dan daerah yang diterima oleh kabupaten/kota untuk desa yang dibagikan secara proporsional.

Perencanaan merupakan tahap awal dalam pengelolaan Alokasi Dana Desa (ADD). Kegiatan perencanaan ini dilakukan untuk menyusun kegiatan pelaksanaan Alokasi Dana Desa ADD. Pertama, tiap dusun akan mengadakan Musyawarah Dusun (Musdus) untuk menampung usulan-usulan masyarakat mengenai program kerja apa saja yang akan dilakukan untuk tahun yang berkenaan (Permendagri No. 113 tahun 2014).

Hasil pengamatan bahwa guna mendorong peningkatan pangan, program-program pembangunan yang pernah dilaksanakan adalah renovasi rumah layak huni. Selain itu guna menyokong program pangan, pemerintah menyediakan bantuan Kredit Usaha Tani (KUT) bagi para petani dalam memberikan permodalan dalam pengelolaan lahannya. Akan tetap program-program tersebut belum mampu meningkatkan kesejahteraan masyarakat amuma karena harga beras lokal masih relative lebih tinggi dibandingkan dengan harga beras impor. Sedangkan dana pengembalian LUT sampai saat ini banyak yang menunggak karena masyarakat tidak mampu membayar cicilan tersebut. Sesuai dengan pengamatan penulis bahwa percepatan pembangunan kampung tidak nampak dan pengelolaan dana desa juga tidak tersentuh pada masyarakat Amuma Distrik Amuma Kabupaten Yahukimo.

Gambaran tentang program indeks daerah tertinggal (IDT dan PPTAD) lebih cenderung pada pembangunan fisik saja sehingga penekanan terhadap pembangunan masyarakat Amuma Distrik Amuma pada umum kurang tersentuh. Padahal berbagai persoalan yang membutuhkan penanganan pembangunan masyarakat desa sesungguhnya sangat mendesak, seperti ketertinggalaan desa dari kota hampir di segala bidang, tidak terakomodasinya keinginan dan kebutuhan masyarakat dalam program-program pemerintah, dan kualiatas pendidikan dan kesejahteraan masih rendah, insfrastruktur jalan yang kurang mendukung dari faktor utama kondisi geografis, suku alam, dan kesenjangan anggaran desa yang belum menyentuh kepada masyarakat kampung Amuma Distrik Amuma.

Berdasarkan pengalaman tersebut sudah seharusnya pendekataan pembangunan pedesaan mulai diarahkan secara integral dengan mempertimbangkan kekhasan daerah Amuma Distrik Amuma baik dilihat dari sisi kondisi, potensi dan prospek dari masing-masing daerah-daerah Kabupaten Yahukimo. Namun di dalam penyusunan kebijakan pembangunan pedesaan secara khusus Kampung Amuma Distrik Amuma belum mengalami sentuhan perubahan kebudayaan masyarakat kampung.

Masyarakat terisoler, belum bersentuhan percepatan pembangunan kampung Amuma Distrik Amuma Kabupaten Yahukimo menjadi persoalan utama untuk membahas tentang pengelolaan dana desa terhadap percepatan pembangunan kampung yang permanen untuk menghilangkan pandangan dan kehidupan modern atau sangat sedikit bersentuhan cara bertani sangat primitif.

\section{Tujuan Penelitian}

1. Mengetahui Berapa Besar pengelolaan alokasi dana desa terhadap Percepatan Pembangunan Kampung Amuma Distrik Amuma Kabupaten Yahukimo. 
2. Mengetahui Pengelolaan Alokasi Dana Desa terhadap Percepatan Pembangunan Kampung Amuma Distrik Amuma Kabupaten Yahukimo.

3. Mengetahui Faktor Apa Saja Mempengaruhi Pengelolaan Alokasi Dana Desa terhadap Percepatan Pembangunan Kampung Amuma Distrik Amuma Kabupaten Yahukimo.

\section{Landasan Teoritis}

Alokasi Dana Desa (ADD)

Undang-Undang No. 6 tahun 2014 Pasal 72 Ayat

1 (d) dan Ayat 4 tentang desa menyatakan pemerintah mengamanatkan bahwa sumber pendapatan desa berasal dari bagian dana perimbangan keuangan pusat dan daerah yang diterima oleh kabupaten/kota untuk desa paling sedikit $10 \%$ setelah dikurangi Dana Alokasi Khusus. Dibagi untuk setiap desa secara proporsional merupakan alokasi dana desa. Sedangkan pengelolaan keuangan Alokasi Dana Desa (ADD) diatur dalam Peraturan Menteri Dalam Negeri Nomer 43 Tahun 2014 Pedoman Pengelolaan Keuangan Desa Pasal 92 Ayat 2 Alokasi Dana Desa berasal dari APBD kabupaten/kota yang bersumber dari bagian dana perimbangan keuangan pusat dan daerah yang diterima oleh kabupaten/kota untuk desa paling sedikit 10 persen. Sedangkan menurut Rocmansjah, (2014:230), Pengelolaan Alokasi Dana Desa (ADD) mengacu pada asas:

1. Asas Merata adalah besarnya bagian alokasi dana desa yang sama untuk setiap desa, yang selanjutnya disebut Alokasi Dana Desa Minimal (ADDM); dan

2. Asas Adil adalah besarnya bagian alokasi dana desa berdasarkan Nilai Bobot Desa (BDx) yang dihitung dengan rumus variabl tertentu, (misalnya jumlah penduduk, luas wilayah, potensi ekonomi, partisipasi masyarakat, kemiskinan, pendidikan dasar, kesehatan, dll), selanjutnya disebut Alokasi dana desa proporsional. Besarnya presentase perbandingan antara azas merata dan adil sebagaimana dimaksud pada ayat (2) diatas, adalah besarnya ADDM adalah $60 \%$ (enam puluh persen) dari jumlah Alokasi Dana Desa (ADD) dan besarnya ADDP adalah 40\% (empat puluh persen) dari jumlah Alokasi Dana Desa (ADD).

\section{Tujuan Alokasi Dana Desa (ADD)}

Alokasi dana desa dimaksudkan untuk membiayai program pemerintah desa dalam pelaksanaan kegiatan pemerintah, pembangunan, dan pemberdayaan masyarakat desa. Tujuan alokasi dana desa menurut Priyo Sambodo, (2014) adalah:

1. Menanggulangi kemiskinan dan mengurangi kesenjangan,

2. Meningkatkan perencanaan dan penganggaran pembangunan ditingkat desa dan pemberdayaan masyarakat,

3. Meningkat pembangunan insfrastruktur pedesaan,
4. Meningkatkan pengamanan nilai-nilai keagamaan sosial budaya dalam rangka mewujudkan peningkatan kesejahteraan masyarakat,

5. Meningkatkan pelayanan kepada masyarakat desa dalam rangka pengembangan kegiatan sosial dan ekonomi msyarakat,

6. Mendorong peningkatan keswadayaan dan gotong royong masyarakat,

7. Meningkatkan pendapatan desa dan masyarakat desa melalui Badan Usaha Milik Desa (BUMDes). Chabib Soleh, Heru Rocmansjah, Op. (2013:62).

Berdasarkan prinsip pengelolaan alokasi dana desa bagian yang tak terpisahkan dari pengelolaan keuangan desa dalam APBD, seluruh kegiatan yang dibiayai alokasi dana desa direncanakan, dilaksanakan, dan dievaluasi secara terbuka dengan melibatkan seluruh lapisan masyarakat desa, semua Kegiatan harus dipertanggung jawabkan secara administratif secara teknis, dan secara hukum, alokasi dana desa dipergunakan secara terarah, ekonomis, efisien, efektif, berkeadilan, dan terkendali. Sedangkan menurut Chabib Soleh, Heru Rocmansjah. Op (2013:62) bahwa jenis kegiatan yang akan dibiayai melalui Alokasi Dana Desa (ADD) sangat terbuka untuk meningkatkan sarana pelayanan masyarakat berupa pemenuhan kebutuhan dasar, penguatan kelembagaan desa dan kegiatan lainnya yang dibutuhkan masyarakat desa yang diputuskan melalui musyawarah desa,

Pengelolaan Alokasi Dana Desa (ADD)

Pengelolaan keuangan Alokasi Dana Desa (ADD) merupakan bagian yang tidak terpisahkan dari pengelolaan keuangan Desa yang dituangkan dalam peraturan Desa tentang APBDesa; 2) Pengelolaan keuangan sebagaimana dimaksud pada ayat (1) harus direncanakan, dilaksanakan, diawasi dan dievaluasi secara terbuka dengan melibatkan seluruh unsur masyarakat di Desa; 3) Pengelolaan keuangan sebagaimana dimaksud ayat (2) harus menggunakan prinsip hemat, terarah, mempunyai dampak pada masyarakat, terukur dan terkendali; 4) Pengelolaan keuangan sebagaimana dimaksud ayat (2) harus dapat dipertanggungjawabkan dan dilaksanakan sesuai dengan ketentuan peraturan perundang-undangan yang berlaku. Dalam rangka mendukung pelaksanaan kelancaran Pengelolaan Alokasi Dana Desa (ADD) dibentuk pelaksana kegiatan tingkat Desa.

Pengelolaan dana desa yang dapat dinilai dengan uang serta segala sesuatu berupa uang dan barang yang berhubungan dengan pelaksanaan hak dan kewajiban desa. Pengelolaan Keuangan seluruh rangkaian kegiatan yang dimulai dari tahap perencanaan, pelaksanaan, penatausahaan, pelaporan hingga pertanggung jawaban yang dilaksanakan dalam satu tahun anggaran, terhitung mulai Januari sampai dengan 31 Desember.

Reformasi dan otonomi daerah sebenarnya adalah harapan baru bagi pemerintah dan masyarakat Desa untuk membangun desanya sesuai dengan kebutuhan dan aspirasi 
masyarakat. Bagi sebagian besar aparat pemerintah Desa, Otonomi adalah satu peluang baru yang dapat membuka ruang kreativitas bagi aparatur Desa dalam mengelola Desa.

Antusiasme masyarakat Desa untuk melakukan pembangunan berbasis pada kebutuhan lokal lagi-lagi terhambat oleh tidak adanya ketersediaan dana yang dapat digunakan sebagai tumpuan operasional pembangunan. Permasalahan lain yang muncul adalah prilaku aparat birokrasi kabupaten yang tidak mau membuka diri dan responsif terhadap tuntutan-tuntutan Desa. Lemahnya sumber daya manusia yang ada di Desa selalu menjadi justifikasi bagi Pemerintah Kabupaten untuk tidak memberikan peluang otonomi bagi Desa.

Laporan pertanggung-jawaban kepala desa selau ditinjau dari sudut pandang aliran pertanggung-jawaban (legal-accountability) penyelenggaraan Pemerintahan Desa oleh Kepala Desa versi UU No 32/2004 maupun PP No $72 / 2005$, terlihat sangat kentara adanya tarikan ke atas. Pasal 15 ayat (2) PP No. 72/2005 menyebutkan bahwa Kepala Desa mempunyai kewajiban untuk memberikan laporan penyelenggaraan Pemerintahan Desa kepada Bupati/Walikota. Tanggung jawab Kepala Desa kepada BPD hanya dalam bentuk penyampaian laporan keterangan pertanggung-jawaban, dan kepada masyarakat hanya menginformasikan laporan penyelenggaraan Pemerintahan Desa.

\section{Percepatan Pembangunan Kampung}

Pembangunan merupakan konsep normatif yang mengisyaratkan pilihan-pilihan tujuan untuk mencapai apa yang disebut sebagai realisasi potensi manusia. Menurut Todaro (1998) pembangunan bukan hanya fenomena semata, namun pada akhirnya pembangunan tersebut harus melampaui sisi materi dan keuangan dari kehidupan manusia bahwa pembangunan ekonomi telah digariskan kembali dengan dasar mengurangi atau menghapuskan kemiskinan, ketimpangan dan pengangguran dalam konteks pertumbuhan ekonomi atau ekonomi negara yang sedang berkembang.

Pada hakekatnya pembangunan kampung/desa dilakukan oleh masyarakat bersama-sama pemerintah terutama dalam memberikan bimbingan, pengarahan, bantuan pembinaan, dan pengawasan agar dapat ditingkatkan kemampuan masyarakat dalam usaha menaikan taraf hidup dan kesejahteraannya. Astrella Janice, (2015) menegaskan bahwa pembangunan desa dilakukan dalam rangka imbang yang sewajarnya antara pemerintah dengan masyarakat. Kewajiban pemerintah adalah menyediakan prasarana-prasarana, selebihnya disandarkan kepada kemampuan masyarakat itu sendiri.

Proses pembangunan desa merupakan mekanisme dari ingin masyarakat yang dipadukan dengan masyarakat. Perpaduan tersebut menentuhkan keberhasilan pembangunan seperti yang dikemukan oleh Ahmadi (2001) meganis pembangunan desa adalah perpaduan yang serasi antara kegiatan partisipasi masyarakat dalam pihak dan kegiatan pemerintah di satu pihak.

Perencanaan pembangunan desa mengacuh pada konsep membangun desa dan desa membangun. Konsep pembangunan desa dalam konteks perencanaan adalah bahwa dalam merencanakan pembangunan, desa perlu mengacuh pada perenacanaan pembangunan kabupaten/kota sampai di desa. Hal tersebut diatur dalam UU Desa terutama dalam pasal 79 dan pasal 80. Dalam pasal 79 UU desa disebutkan bahwa:

a. Pemerintah desa menyusun perencanaan pembangunan desa dengan kewenangannya dengan mengacuh pada perenacanaan pembangunan kabupaten/kota sampai di desa.

b. Perencanaan pembangunan desa sebagaimana dimaksud pada ayat 1 disusun secara berjangka meiliputi: 1) rencana pembangunan jangka menengah desa untuk jangka waktu 6 tahun, 2) rencana pembangunan tahunan desa atau yang disebut rencana kerja pemerintah desa, merupakan penjabaran dari rencana pembangunan jangka menengah desa untuk jangka waktu 1 tahun.

c. Rencana pembangunan jamgka menengah desa dan rencana kerja pemerintah desa sebagai dimaksud pada ayat 2 ditetapkan peraturan desa.

d. Peraturan desa tentang rencana pembangunan jangka menengah desa dan rencana kerja pemeritah desa merupakan satu-satunya dukumen perencanaan di desa.

e. Rencana pembangunan jangka menengah desa dan rencana kerja pemerintah desa merupakan pedoman dalam penyusunan anggaran pendapatan dan belanja desa yang diatur dalam peraturan pemerintah.

f. Program pemerintah yang berskala lokal desa di koordinasikan dan/atau didelekasikan pelaksanaanya kepada desa.

g. Perencanaan pembangunan desa sebagai di maksud pada ayat 1 merupakan salah sumber masukan dalam perencanaan pembangunan kabupaten/kota sampai di desa.

Pada UU Desa untuk mengakomodir asas demokrasi, kemandirian, partisipasi, kesetaraan dan pemberdayaan, perencanaan pembangunan desa tidak semata-mata bersifat top down, namun juga menyusun konsep desa membangun. Konsep desa membangun ini mendepankan musawara desa untuk memenuhi kebutuhan riil masyarakat hal tersebut dijelaskan dalam pasal $80 \mathrm{UU}$ Desa yang menyebutkan bahwa:

a. Perencanaan pembangunan desa sebagai mana dimaksud dalam pasal 79 di selenggarahkan dengan mengikutsertakan masyarakat desa.

b. Dalam menyusun perencanaan pembangunan desa sebagai dimaksdu pada ayat 1 , pemerintah desa wajib menyelenggarahkan musjawara perencanaan pembangunan desa.

c. Musawara perencanaan pembangunan desa menetapkan prioritas, program, kegiatan dan 
kebutuhan pembangunan desa yang didanai oleh anggaran pendapatan dan belanja desa, swadaya masyarakat desa, dan/atau anggaran pendapatan dan belanja daerah kabupaten/kota sampai di desa.

d. Prioritas, program, kegiatan dan kebutuhan pembangunan desa sebagaimana dimksud pad ayat 3 dirumuskan berdarkan penilaian terhadap kebutuhan masyarkat desa yang meiliputi: 1) peningkatan kualitas dan akses terhadap pelayanan dasar, 2) pembangunan dan pemeliharaan infrastruktur dan lingkungan berdasarkan kemampuan teknis dan sumber daya lokal yang tersediah, 3) pengembangan ekonomi pertanian berskala produktif, 4) pembangunan dan pemanfaatan teknolgi tepat guna untuk kemajuan ekonomi, 5) peningkatan kualitas ketertiban dan ketentraman masyarakat desa berdasarkan kebutuhan masyarakat desa.

\section{Masyarakat Pedesaan}

Menurut Shadily, (1993:47) menyatakan bahwa masyarakat dan pedesaan atau desa, dua kata yang mempunya arti tersendiri. Untuk mendapatkan pengertian dari dua kata ini harus diartikan terlebih dahulu kata perkata. Misalnya, masyarakat diartikan golongan besar atau kecil yang terdiri dari beberapa manusia dengan atau karena sendirinya bertalian secara golongan dan pengaruhmempengaruhi satu sama lain.

Menurut Koentjaraningrat, (2002:144) menyatakan bahwa masyarakat dapat juga diartikan sebagai sekumpulan manusia yang saling berinteraksi. Dari pemaparan diatas sudah di jelaskan bahwasanya masyarakat pedesaan adalah dua kata yang terpisah atau mempunyai arti tersendiri, untuk bisa mendapatkan pengertian dari dua kata tersebut maka harus diartikan terlebih dahulu dari kata perkata sehingga dari dua kata tersebut bisa di jadikan satu arti yang seperti di harapkan.

Menurut Rahardjo, (2011:28) Pandangan tentang kedua kata diatas yaitu masyarakat pedesaan atau desa dapat diartikan sebagai masyarakat yang memiliki hubungan yang lebih mendalam dan erat dan sistem kehidupan umumnya berkelompok dengan dasar kekeluargaan. Sebagian besar warga masyarakat hidup dari pertanian. Masyarakat tersebut homogen, seperti dalam hal mata pencaharian, agama, adat-istiadat dan sebagainya. Dengan kata lain masyarakat pedesaan identik dengan istilah gotong royong yang merupakan kerja sama untuk mencapai kepentingan kepentingan mereka.

\section{Karakteristik Masyarakat Pedesaan}

Menurut Rahardjo, (2011:30) menyatakan bahwa masyarakat desa selalu memiliki ciri-ciri atau dalam hidup bermasyarakat, biasanya tanpak dalam perilaku keseharian mereka. Pada situasi dan kondisi tertentu, sebagian karakteristik dapat digeneralisasikan pada kehidupan masyarakat desa di daerah tertentu.
Masyarakat desa juga ditandai dengan pemilikan ikatan perasaan batin yang kuat sesama warga desa, yaitu perasaan setiap warga/anggota masyarakat yang amat kuat dan pada hakekatnya bahwa seseorang merasa merupakan bagian yang tidak dapat dipisahkan dari masyarakat itu sendiri dimanapun ia hidup dicintainya serta mempunyai perasaan bersedia untuk berkorban setiap waktu demi masyarakatnya atau anggota-anggota masyarakat, karena beranggapan sama-sama sebagai masyarakat yang saling mencintai saling menghormati, mempunyai hak tanggung jawab yang sama terhadap keselamatan dan kebahagiaan bersama di dalam masyarakat.

Yang menjadi ciri masyarakat pedesaan antara lain; pertama, di dalam masyarakat pedesaan di antara warganya mempunyai hubungan yang lebih mendalam dan erat bila dibandingkan dengan masyarakat pedesaan lainnya di luar batas wilayahnya. Kedua, sistem kehidupan umumnya berkelompok dengan dasar kekeluargaan. Ketiga, sebagian besar warga masyarakat pedesaan hidup dari pertanian. Keempat, masyarakat tersebut homogen, deperti dalam hal mata pencaharian, agama, adat istiadat, dan sebagainya. Tetapi Raharjdo (2011:34) menambahkan bahwa sejumlah sosiolog dalam merumuskan karakteristik masyarakat cenderung mengacu pada pola-pola pikiran yang bersifat teoritik, seperti konsep dari Ferdinand Tonnies (1855-1936), Emile Durkheim (1858-1917) dan Charles Horton Cooley (1864-1929).

\section{Metodologi Penelitian Jenis Data}

Data adalah catatan atas kumpulan fakta yang ada di lapangan, merupakan hasil pengukuran atau pengamatan suatu variabel yang bentuknya dapat berupa angka, katakata atau citra. Jenis data yang digunakan dalam penelitian ini adalah:

a. Data Primer

Data primer adalah data yang diperoleh secara langsung dari penelitian dalam hal ini data yang bersumber dari wawancara. Penentuan informan kunci tidak hanya didasarkan atas keterwakilan sampel tetapi ditentukan oleh dua hal pokok yakni baik informant dan keterlibatan menurut Tresiana,(2013:86). Sehingga peneliti langsung turun lapangan untuk melakukan wawancara kepada informan untuk menggali secara mendalam mengenai pengelolaan Dana Desa kepada masyarakat Amuma yang menjadi kunci pengelolaan dana desa mulai dari kepala desa, perangkat desa.

b. Data Sekunder

Data sekunder adalah data yang diperoleh dari literatur yang ada kaitannya dengan judul yang akan diteliti. Seperti peraturan perundang-undangan diantaranya Peraturan Pemerintah Nomor 47 tahun 2015 tentang Pedoman Pelaksanaan Undang-Undang Nomor 6 tahun 2014, Permenkeu Nomor 93/PMK.07/2015 tentang Tata Cara Pengalokasian, Penyaluran, Penggunaan, Pemantauan, dan Evaluasi Dana Desa, Peraturan bupati tentang tata cara 
pembagian dan penetapan rincian dana kampung amuma Kabupaten Yahukimo tahun Anggaran 2016.

\section{Sumber Data}

Sumber data utama dalam penelitian kualitatif adalah kata-kata dan tindakan, selebihnya adalah data tambahan seperti dokumen dan lain-lain, Lofland dan Lofland dalam Moleong (2011:157). Sumber data dalam penelitian ini adalah:

a. Informan

Sumber data primer diperoleh dengan cara menggali informasi langsung melalui wawancara kepada informan penelitian di lapangan.

b. Dokumen

Sumber data ini merupakan berbagai dokumen yang berhubungan dengan pengelolaan dana desa yang ada di kampung Amuma Distrik Amuma. Selanjutnya akan digunakan untuk membantu menganalisis dalam pengelolaan Dana Desa 2016-2019 yang telah dijalankan oleh pemerintahan desa dengan dokumendokumen antara lain:

1) Permenkeu Nomor 93/PMK.07/2016 tentang Tata Cara Pengalokasian, Penyaluran, Penggunaan, Pemantauan, dan Evaluasi Dana Desa,

2) Peraturan Bupati tentang tata cara pembagian dan penetapan rincian dana kampung setiap kampung Kabupaten Yahukimo tahun Anggaran 2016

3) Rencana Kerja Pemerintahan (RKP) desa tahun 2016,

4) Dokumen anggaran dana desa 2016 (perencanaan, pengelolaan dan pertanggungjawaban (SPJ),

5) Demografi desa dan profil desa dan Dokumentasi pengelolaan dana kampung 2016.

\section{Satuan Pengamatan Dan Satuan Analisis}

Menurut Gulo, (2005:77) bahwa satuan analisis ini mengandung perilkau atau karakteristik yang diteliti. Satuan pengamatan adalah satuan tempat informasi diperoleh tentang satuan analisis. Istilah lain satuan analisis adalah unit analisis, sedangkan satuan pengamatan adalah sumber data, maka satuan pengamatan dalam penelitian ini adalah kepala Desa Amuma Distrik Amuma Kabupaten Yahukimo.

Menurut Arikunto (2002:121) menyatakan bahwa yang dimaksud dengan unit analisis dalam penelitian adalah satuan tertentu yang diperhitungkan sebagai subjek penelitian. Berdasarkan pengertian tersebut maka, satuan analisis dalam penelitian ini adalah jawaban dari wawancara langsung yang diberikan oleh kepala Desa Amuma Distrik Amuma Kabupaten Yahukimo yang juga sebagai satuan pengamatan.

Metode Analisis Data

Metode yang digunakan untuk menganalisis data adalah metode deskriptif. Metode deskriptif adalah jumlah variabel yang berkenan dengan masalah yang diteliti antara fenomena dan gambaran akurat tentang Pengelolaan Alokasi Dana Desa (ADD) tahun 2015-2019 dan pembangunan sebagai subyek penelitian. Penelitian ini dianalisis secara kualitatif dengan menggunakan model analisis interaktif.

\section{Analisis Dan Pembahasan}

\section{Jumlah Alokasi Dana Desa Yang Diterima di Distrik} Amuma Kabupaten Yahukimo

Alokasi Dana Desa (ADD) yang merupakan bagian dari dana perimbangan diterima Kabupaten Yahukimo cukup besar dan penulis di temukan bahwa Alokasi Dana Desa (ADD) hanya beberapa bidang prioritas yang telah dilaksanakan oleh kepala desa yakni: pembangunan balai desa, rumah pribadi kepala kampung dan pembayaran honor bagi aparat kampung. Dengan anggaran pendapatan dan belanja desa yang di anggarkan oleh Pemerintah Daerah Kabupaten Yahukimo dari Alokasi Dana Desa (ADD) yang diterima oleh Kepala Kampung di sajikan dalam tabel sebagai berikut:

Tabel 4.1

Jumlah Penerimaan Alokasi Dana Desa (ADD) Tahun 2016-2019

\begin{tabular}{|c|c|c|}
\hline No & Tahun & Alokasi Dana Desa (ADD) \\
\hline 2 & 2016 & $\operatorname{Rp~623.671.035~}$ \\
\hline 3 & 2017 & $\operatorname{Rp~549.266.883~}$ \\
\hline 4 & 2018 & $\operatorname{Rp~752.110.000~}$ \\
\hline 5 & 2019 & $\operatorname{Rp~830.662.000~}$ \\
\hline
\end{tabular}

Sumber data: Dokumen Desa Kampung Amuma Tahun 2020

Dari tabel 4.1 diatas diketahui jumlah penerimaan Alokasi Dana Desa (ADD) yang diterima oleh kepala desa kampung dengan berjumlah dari tahun 2016-2019 sedikit penurunan pada tahun 2017 sebanyak Rp 549.266.883 berbeda dari setiap tahun. Karena, kurangnya transfaransi pemerintah daerah menangani anggaran dengan jumlah yang cukup besar dalam anggaran dari penerimaan Alokasi Dana Desa per-tahun.

Pada jumlah Penerimaan Alokasi Dana Desa (ADD) yang diturunkan pemerintah melalui III tahap, yaitu tahap pertama sebesar $20 \%$ dan tahap ke dua sebesar $40 \%$ dan tahap ketiga sebesar $40 \%$. Dari setiap tahapan sesuai dengan jumlah penduduk, luas wilayah, potensi ekonomi desa. Harapan masyarakat kampung Amuma bahwa bisa dirasakan dengan percepatan pembangunan kampung dari setiap alokasi dana desa yang begitu cukup besar di telingga masyarakat.

Sedangkan jumlah pendapatan yang diperoleh desa dari hasil Alokasi Dana Desa (ADD), Dana Bagi Hasil Pajak (BHP), Bantuan Kabupaten Yahukimo selalu ada tahapan dari alokasi anggaran yang berasal dari APBN ini bersumber dari belanja pusat disusun berdasarkan asumsi realisasi pendapatan desa tahun 2016-2019 dengan potensi yang menjadi sumber pendapatan asli desa, bagian dana perimbangan, 
bantuan keuangan dari pemerintah, daerah dan provinsi, hibah dan sumbangan pihak ketiga.

Jumlah Alokasi Dana Desa (ADD) yang diterima oleh kepala kampung tersebut dilakukan sesuai dengan prosedur tentang pengelolaan alokasi dana desa dari setiap tahunnya di sesuaikan dengan jumlah penduduk dan kondisi ekonomi daerah. Alokasi Dana Desa (ADD) merupakan perolehan bagian keuangan desa dari Kabupaten yang penyalurannya melalui kas desa.

Kas desa sangat bermanfaat bila mengelola keuangan harus memiliki akuntabilitas dan transparansi agar dukungan keuangan dari Pemerintah ini dapat meningkatkan sektor ekonomi dalam pembangunan Desa jalan secara baik dan aman. karena pembangunan fisik dan dampak timbul dari pengelolaan dana desa dan percepatan pembangunan kampung harus mampu Pengelolaan dana desa masih kurang dirasakan oleh masyarakat kampung, sekalipun bantuan Pemerintah Daerah tentang dana desa ini cukup besar, tetapi percepatan pembangunan kampung sangat terlambat.

Dan hal ini dapat disimpulkan bahwa kepala kampung harus memahami Peraturan Menteri Dalam Negeri Nomor 133 tahun 2014 tentang pedoman pengelolaan keuangan desa disebutkan pada Bab 3 Pasal 3 ayat 1 bahwa kepala desa sebagai kepala pemerintah desa adalah pemegang kekuasaan pengelolaan dana desa yang mewakili pemerintah desa dalam kepemilikan kekayaan desa yang dipisahkan dengan tugas kewenangan dalam pengelolaan dana desa dengan kebijakannya.

Tugas dan kewenangan saya sebagai kepala desa saya menetapkan kebijakan tentang pengelolaan barang desa, menetapkan kebijakan tentang pelaksanaan APBDes, menetapkan bendahara desa, dan menetapkan petugas yang melakukan pengelolaan barang milik desa. Kepala desa sebagai kepala pemerintah desa yang kecil di kampung Amuma maka, pemegang kekuasaan pengelolaan dana desa dan mewakili pemerintah desa dalam kepemilikan kekayaan desa yang dipisahkan.

Dapat disimpulkan kepala kampung kurang paham dengan prosedur keuangan desa menurut UU No. 6 tahun 2014 tentang desa, seperti yang disebutkan dalam pasal 1 ayat (1) bahwa dana desa adalah semua hak dan kewajiban desa yang dapat dinilai dengan uang serta segala sesuatu berupa uang dan barang yang berhubungan dengan pelaksanaan hak dan kewajiban desa. Pengelolaan dana desa ada beberapa aspek perencanaan penganggaran, pelaporan, akuntabilitas finansial, serta pengawasan keuangan desa di Distrik Amuma Kabupaten Yahukimo.

2. Pengelolaan Alokasi Dana Desa (ADD) di Distrik Amuma Kabupaten Yahukimo

Pengelolaan Alokasi Dana Desa Kampung Amuma Distrik Amuma Kabupaten Yahukimo disajikan dalam tabel 4.2 sebagai berikut:

\section{a. Perencanaan}

Proses Perencanaan Penggunaan Alokasi Dana Desa (ADD)

\begin{tabular}{|c|c|c|c|}
\hline $\begin{array}{l}\text { No } \\
\text { (1) }\end{array}$ & $\begin{array}{c}\text { Tahapan } \\
\text { (2) }\end{array}$ & $\begin{array}{c}\text { Aktor/ } \\
\text { Pemeran } \\
\text { (3) }\end{array}$ & $\begin{array}{l}\text { Analisis } \\
\text { (4) }\end{array}$ \\
\hline 1 & $\begin{array}{c}\text { Rapat kepala } \\
\text { kampung }\end{array}$ & $\begin{array}{l}\text { Kepala } \\
\text { kampung, } \\
\text { Tokoh } \\
\text { masyarakat } \\
\text { dan } \\
\text { Masyarakat }\end{array}$ & \begin{tabular}{lr}
\multicolumn{2}{l}{ Proses perencanaan } \\
ADD & yang \\
dilakukan & oleh \\
kepala & Desa \\
Amuma & masih \\
kurang melibatkan \\
partisipasi seluruh \\
komponen yang \\
ada di Desa baik \\
lembaga \\
kemasyarakatan \\
maupun \\
masyarakat umum.
\end{tabular} \\
\hline 2 & $\begin{array}{c}\text { Rapat Kecil- } \\
\text { kecilan }\end{array}$ & $\begin{array}{l}\text { Kepala Desa, } \\
\text { Kepala suku } \\
\text { dan } \\
\text { Perangkat } \\
\text { Desa }\end{array}$ & $\begin{array}{l}\text { Rapat yang } \\
\text { dilaksanakan sudah } \\
\text { melibatkan Kepala } \\
\text { Desa, Kepala suku } \\
\text { dan Perangkat Desa }\end{array}$ \\
\hline 3 & Survey & \begin{tabular}{ll}
\multicolumn{2}{l}{ Kepala Desa } \\
dan Kepala \\
suku
\end{tabular} & $\begin{array}{l}\text { Pemerintah } \\
\text { Amuma besa } \\
\text { melakukan Survey } \\
\text { terlebih dahulu } \\
\text { sebelum membuat } \\
\text { Surat-Surat } \\
\text { Keterangan ADD. }\end{array}$ \\
\hline 4 & Format RKP & Kepala Desa & $\begin{array}{l}\text { Format RKP dibuat } \\
\text { oleh Tim } \\
\text { Pendamping Desa } \\
\text { penyusun RKP } \\
\text { juga belum lengkap } \\
\text { dan kebijakan yang } \\
\text { telah di tentukan } \\
\text { oleh Kepala Desa }\end{array}$ \\
\hline 5 & $\begin{array}{l}\text { Membuat } \\
\text { daftar } \\
\text { kebutuhan } \\
\text { masyarakat }\end{array}$ & Kepala Desa & $\begin{array}{lr}\text { Dalam membuat } \\
\text { daftar kebutuhan } \\
\text { masyarakat kepala } \\
\text { Desa } \quad \text { belum } \\
\text { mengacu pada } \\
\text { rapat internal. }\end{array}$ \\
\hline 6 & $\begin{array}{l}\text { Pembentukan } \\
\text { TIMpelaksana } \\
\text { kegiatan } \\
\text { ADD }\end{array}$ & Kepala Desa & $\begin{array}{l}\text { Kepala Desa belum } \\
\text { membentuk TPK } \\
\text { ADD sesuai } \\
\text { dengan Peraturan } \\
\text { yang ada. }\end{array}$ \\
\hline 7 & $\begin{array}{l}\text { Musrenbang } \\
\text { Desa }\end{array}$ & $\begin{array}{l}\text { Camat, } \\
\text { Kepala Desa, } \\
\text { BPD, } \\
\text { LPMD, } \\
\text { Tokoh } \\
\text { Masyarakat, } \\
\text { dan } \\
\text { Masyarakat. }\end{array}$ & 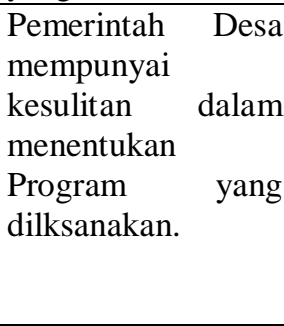 \\
\hline
\end{tabular}


JURNAL EKONOMI \& BISNIS

Sekolah Tinggi Ilmu Ekonomi Port Numbay Jayapura
p-ISSN : 2086-4515 | e-ISSN : 2746-1483

Volume 12, Nomor 1, Juli 2021

ejurnal.stie-portnumbay.ac.id

\begin{tabular}{|c|l|l|l|}
\hline 8 & Evaluasi & $\begin{array}{l}\text { Kepala suku, } \\
\text { Masyarakat, } \\
\text { BPD, } \\
\text { LPMD }\end{array}$ & $\begin{array}{l}\text { Dilakukan untuk } \\
\text { melihat kesesuaian } \\
\text { dan ketepatan } \\
\text { program tetapi, } \\
\text { belum terlaksana. }\end{array}$ \\
\hline 9 & $\begin{array}{l}\text { Penetapatan } \\
\text { RKP Desa }\end{array}$ & $\begin{array}{l}\text { Kepala Desa } \\
\text { dan BPD }\end{array}$ & $\begin{array}{l}\text { Belum } \\
\text { dilaksanakan } \\
\text { apabila } \\
\text { disepakati. }\end{array}$ \\
\hline 10 & $\begin{array}{l}\text { Penyusunan } \\
\text { RPD }\end{array}$ & $\begin{array}{l}\text { Tim } \\
\text { Pelaksana } \\
\text { Kegiatan }\end{array}$ & $\begin{array}{l}\text { RPD juga belum } \\
\text { seraturan berdasarkan } \\
\text { tentang APBDesa } \\
\text { dan data harga } \\
\text { Pasar. }\end{array}$ \\
\hline
\end{tabular}

Sumber: Analisis Data Primer, 2020

Hasil pengamatan secara langsung yang telah dilakukan, bahwa perencanaan penggunaan Alokasi Dana Desa (ADD) Desa Amuma di Distrik Amuma Kabupaten Yahukimo penerapan belum di lakukan dan tidak sesuai dengan pernyataan dalam pengamatan dan tidak sesuai dengan Peraturan yang berlaku. Hal tersebut dapat terlihat dengan kesesuaian antara perencanaan yang dilakukan dengan penyusunan rencana kegiatan yang diatur dalam petunjuk teknis alokasi dana desa.

b. Pelaksanaan

Pelaksanaan adalah suatu tindakan atau pelaksanaan dari sebuah rencana yang sudah disusun secara matang dan terperinci, implementasi biasanya dilakukan setelah perencanaan sudah dianggap siap. Pelaksanaan Alokasi Dana Desa (ADD) Kepala Desa bertindak sebagai penanggungjawab pengelolaan kegiatan yang bersumber dari Alokasi Dana Desa (ADD). Kepala desa sebagai Penanggung jawab saja untuk TPK ADD (Tim pelaksana kegiatan) belum pernah di bentuk, untuk tim pelaksana kegiatan ADD tingkat Desa 3 orang terdiri dari Perangkat Desa, LPMD, dan masyarakat untuk mengetahui ketepatan penggunaan Alokasi Dana Desa (ADD), masyarakat tersebut sebagai informan.

Pelaksanaan penggunaan Alokasi Dana Desa (ADD) yang dilaksanakan oleh kepala desa amuma mendapat kritikan dari masyarakat dari segi perencanaan musrenbang desa. Pengamatan penelitipun sama bahwa perencanaan musrenbang hanya sebagai formalitas saja semua di kerjakan oleh kepala kampung dengan pendamping desa. Pada hal sudah memang sepakati bersama untuk mengetahui kemungkinan hanya masyarakat tertentu saja, apa lagi program yang dilaksanakan selalu sama setiap tahunnya, kebanyakan dalam perencanaannya lebih penting daripada itu. Pembangunan yang lakukan pemerintah desa lebih cenderung mengutamakan rumah sendiri dan kampung tertentu.

Pelaksanaan Penggunaan Alokasi Dana Desa (ADD)

\begin{tabular}{|c|c|c|c|}
\hline No & Uraian & $\begin{array}{c}\text { Rincian Anggaran } \\
(\mathrm{Rp})\end{array}$ & Keterangan \\
\hline 1 & $\begin{array}{l}\text { Penghasilan tetap Kepala Desa dan } \\
\text { Perangkat Desa } \\
\text { - Kepala Desa } 1 \text { Orang } \\
\text { - Sekdes 1 Orang } \\
\text { - Kaur 3 Orang }\end{array}$ & $\begin{array}{l}\text { Rp 3.500.000; } \\
\text { Rp 2.800.000; } \\
\text { Rp 4.200.000; }\end{array}$ & $\begin{array}{l}\text { Honor : } \\
7 \text { bln@ } 500.000 \\
7 \text { bln@ } 400.000 \\
7 \text { bln@300.000 }\end{array}$ \\
\hline & & Rp 10.500 .00 & \\
\hline 2 & $\begin{array}{l}\text { Insentif : } \\
\text { - Kepala Desa 1 Orang } \\
\text { - Sekdes 1 Orang } \\
\text { - Kaur } 2 \text { Orang } \\
\text { - Bendahara 1 Orang } \\
\text { - Ketua Bamuskan 1 Orang } \\
\text { - Wakil Bamuskan 1 Orang } \\
\text { - Sekretaris Bamuskan 1 org } \\
\text { - Angota Bamuskan } 4 \text { Orang }\end{array}$ & $\begin{array}{l}\operatorname{Rp} 2.100 .000 \\
\operatorname{Rp} 1.750 .000 \\
\operatorname{Rp} 2.800 .000 \\
\operatorname{Rp} 4.500 .000 \\
\operatorname{Rp} 3.850 .000 \\
\operatorname{Rp} 3.150 .000 \\
\operatorname{Rp} 2.450 .000 \\
\operatorname{Rp} 8.400 .000\end{array}$ & ADD \\
\hline & & Rp 29.000.000; & \\
\hline 3 & $\begin{array}{l}\text { Operasional balai desa } \\
\text { - Belanja ATK untuk kepala } \\
\text { kampung dan perangkat }\end{array}$ & Rp 11.139.244 & ADD \\
\hline 4 & Total Transaksi Kumulatif & $\operatorname{Rp} 50,639,244$ & $\begin{array}{ll}\text { Belanja tahan } \\
\text { pertama. }\end{array}$ \\
\hline
\end{tabular}

Sumber: Analisis Data Primer, 2020

Berdasarkan analisis penggunaan Alokasi Dana Desa (ADD) Di Desa Amuma, terlihat bahwa Pencatatan penggunaan Alokasi Dana Desa (ADD) telah dilakukan dengan baik. Penggunaan Alokasi Dana Desa (ADD) pada bidang Operasional pemerintahan maupun pada bidang pelaksanaan 
pembangunan Desa telah dirincikan dengan baik Alokasi penggunaanya telah sesuai dengan Peraturan yang ada. Tetapi masih banyak masyarakat yang belum merasakan pembangunan secara merata sesuai dengan harapan masyarakat.

\section{c. Penatausahaan}

Penataan keuangan Desa adalah seluruh kegiatan keuangan yang dilakukan oleh pemerintahan desa yakni Bendahara Desa terdiri dari Penatausahaan penerimaan dan Penatausahaan pengeluaran serta pelaporan pertanggungjawabannya kepada pihak yang berkepentingan. Kepala Desa memegang kuasa tertinggi dalam pengelolaan keuangan Desa karena jabatannya sebagai kepala pemerintahan di tingkat Desa.

Bendahara Desa wajib melakukan pencatatan setiap penerimaan dan pengeluaran serta melakukan tutup buku setiap akhir bulan secara tertib dan Bendahara Desa wajib mempertanggungjawabkan uang melalui laporan pertanggungjawaban. Laporan pertanggungjawaban disampaikan setiap bulan kepada Kepala Desa paling lambat tanggal 10 bulan berikutnya. Namun semua dikerjakan oleh pendamping desa setiap dokumen yang digunakan oleh bendahara dalam melakukan penatausahaan penerimaan dan pengeluaran antara lain, buku kas umum, buku kas pembantu pajak dan buku bank.

Buku kas umum digunakan untuk mencatat seluruh bukti transaksi keuangan desa. Buku kas pembantu pajak digunakan untuk mencatat bukti transaksi terkait dengan pemungutan maupun penyetoran pajak oleh bendahara desa. Buku bank digunakan untuk mencatat bukti transaksi terkait dengan penerimaan maupun pengeluaran melalui bank. Semua dikerjakan oleh pendamping dengan alasan bendahara tidak mampu, sehingga semua laporan penataan keuangan desa belum transparan terhadap masyarakat dari hasil analisis penatausahaan pengelolaan Keuangan Desa yang dilakukan oleh pendamping desa bukan Bendahara Desa di lihat pada:

Tabel 4.4

Penatausahaan Alokasi Dana Desa (ADD)

\begin{tabular}{|l|l|l|l|}
\hline $\begin{array}{l}\text { No } \\
(1)\end{array}$ & \multicolumn{1}{|c|}{$\begin{array}{c}\text { Tahapan } \\
(2)\end{array}$} & \multicolumn{1}{|c|}{$\begin{array}{c}\text { Aktor/Pemeran utama } \\
(3)\end{array}$} & \multicolumn{1}{c|}{$\begin{array}{c}\text { Analisis } \\
(4)\end{array}$} \\
\hline 1 & $\begin{array}{l}\text { Penatausahaan } \\
\text { penerimaan }\end{array}$ & $\begin{array}{l}\text { Kepala kampung dan } \\
\text { Pendamping Desa }\end{array}$ & $\begin{array}{l}\text { Pencatatan penerimaan keuangan masih belum } \\
\text { dilaksanakan dengan baik. }\end{array}$ \\
\hline 2 & $\begin{array}{l}\text { Penatausahaan } \\
\text { pengeluaran }\end{array}$ & $\begin{array}{l}\text { Kepala kampung dan } \\
\text { Pendamping Desa }\end{array}$ & $\begin{array}{l}\text { Pencatatan pengeluaran keuangan belum } \\
\text { dilaksanakan dengan baik. }\end{array}$ \\
\hline 3 & $\begin{array}{l}\text { Pelaporan } \\
\text { Pertanggungjawaban }\end{array}$ & $\begin{array}{l}\text { Kepala Desa dan } \\
\text { Bendahara Desa }\end{array}$ & $\begin{array}{l}\text { Setiap bulan desa melaporkan kondisi keuangan } \\
\text { desa kepada kepala desa. }\end{array}$ \\
\hline
\end{tabular}

Sumber: Analisis Data Primer, 2020

Kendala yang dilami pada saat melakukan Penatausahaan adalah belum mahirnya menggunakan komputer dan belum adanya pelatihan yang dilaksanakan oleh pihak yang berwenang. Kendala yang dialami karena kepala kampung tidak mau tahu, masukan dari setia masyarakat belum dengar. Apalgi yang lain? Hanya yang mahir menggunakan komputer adalah pendamping desa sehingga banyak manfaatkan oleh pendamping-pendamping desa ini dan tidak adanya pelatihan khusus untuk Bendahara baru apalagi faktor umur, pada tahun 2016-2019 ada tawaran dari mahasiswa untuk mengadakan Pelatihan komputer untuk perangkat Desa tapi tidak di berikan Izin oleh BPMD karena Untuk Dana Pemberdayaan tidak boleh digunakan untuk Aparat Desa, Pelatihan bisa dilaksanakan asalkan di ambil dari dana Sumber Daya Manusia.

Dalam melaksanakan Penatausahaan yang di lakukan oleh kepala Desa amuma dalam hal ini Pelaksana Tugas Pengelolaan Keuangan Desa (PTPKD) belum ada peraturan yang ada di Peraturan Bupati Yahukimo tentang pengelolaan keuangan desa dan bahwa dengan adanya Penatausahaan yang dilakukan kepala desa dan

pendamping desa berupa Buku Kas Umum, Buku Kas, Pembantu Pajak dan Buku Bank sangat mempermudahkan BPD dan masyarakat untuk mengetahui ada atau tidak adanya penyelewengan dari dana yang begitu besar dipegang atau dikelola Pemerintah Desa.

d. Pelaporan

Penulis melakukan penelitian terhadap proses pelaporan yang dilakukan oleh kepala desa Amuma dalam melaksanakan pelaporan Alokasi Dana Desa (ADD), pelaporan penggunaanya dilaksanakan dalam tiga tahap yaitu tahap akhir tahun pertama dan tahun kedua dan dibuatkan oleh pendamping desa. Untuk Pengelolaan Alokasi Dana Desa memang sudah ada aturannya. Biasanya kita pedomani peraturan tentang petunjuk teknis alokasi dana desa dan Perbup tentang pengelolaan keuagan desa.

Pelaporan penggunaan Alokasi Dana Desa dilaporkan dalam dua tahap yaitu tahap tahun pertama paling lambat akhir bulan juli dan tahun dua paling lambat bulan januari tapi tanpa pengetahuan sekertaris dan bendahara ya begitulah semua kepala kampung sama laporan berkala dilaksanakan pada bulan januari dan diserahkan 
paling lambat akhir bulan juni ke BPMDK dan BPKD untuk melakukan pencairan dana. Selanjutnya, untuk laporan akhir dilaksanakan bulan agustus dan diserahkan paling lambat bulan januari sebelum diterima oleh BPMDK dan BPKD, Laporan tersebut di verifikasi oleh Tim Pendamping Desa.

Berdasarkan hasil pengamatan yang dilakukan, pelaporan penggunaan Dana Desa (ADD) terdiri atas laporan berkala dan laporan akhir. Proses pembuatan laporan berkala dan laporan akhir terbilang sama namun berbeda pada lampiran laporan. Berikut digambarkan proses pelaporan penggunaan Alokasi Dana Desa (ADD). Hasil analisis terhadap Pelaporan Penggunaan Alokasi Dana Desa di Desa Amuma di lihat pada:

Tabel 4.5

Pelaporan penggunaan Alokasi Dana Desa (ADD)

\begin{tabular}{|c|c|c|}
\hline $\begin{array}{c}\text { Jenis laporan jenis } \\
\text { laporan }\end{array}$ & Proses & Analisis \\
\hline 1. Laporan Berkala & Laporan tingkat Desa & $\begin{array}{l}\text { Laporan realisasi penggunaan dana yang dibiayai oleh ADD } \\
\text { tidak sesuai dan tidak dilaksanakan secara berjenjang oleh } \\
\text { kepala Desa kepada TIM pendamping desa dan kepala desa } \\
\text { tidak melihat itu. }\end{array}$ \\
\hline \multirow{3}{*}{$\begin{array}{l}\text { 2. Laporan Akhir } \\
\\
\text { - } \text { Pelaksanaan } \\
\text { - } \text { Penyerapan Dana } \\
\text { - } \text { Masalah yang } \\
\text { - dihadapi }\end{array}$} & $\begin{array}{l}\text { Laporan ke Bupati cq. } \\
\text { BPMDK untuk di } \\
\text { Verifikasi }\end{array}$ & $\begin{array}{l}\text { Dokumen yang butuhkan dalam melakukan proses pencairan } \\
\text { dana terlebih dahulu harus diverifikasi oleh Tim dari } \\
\text { BPMDK karena tugas BPMDK adalah melakukan } \\
\text { pembinaan kepada Desa. Tapi selama penulis analisis tidak } \\
\text { sesuai dengan meganismenya. }\end{array}$ \\
\hline & $\begin{array}{l}\text { Rekomendasi } \\
\text { verifikasi }\end{array}$ & $\begin{array}{l}\text { Dokumen yang di butuhkan tidak sesuai, maka rekomendasi } \\
\text { hasil verifikasi tersebut di bawa ke BPKD unutk melakukan } \\
\text { pencairan dan tidak sesuai aturan. }\end{array}$ \\
\hline & Pencairan Dana & $\begin{array}{l}\text { Proses penyampaian laporan penggunaan dana ADD harus } \\
\text { tepat waktu, namun pemerintah Desa Amuma tidak } \\
\text { melaksankan pelaporan dengan tepat waktu atau sesuai } \\
\text { dengan aturan yang ada karena yang mengetahui cara } \\
\text { pembuatannya telah dialihkan ke pendamping desa dan di } \\
\text { ganti oleh sekretaris Desa. }\end{array}$ \\
\hline
\end{tabular}

Sumber: Analisis Data Primer, 2020

Pelaporan Alokasi Dana Desa (ADD) yakni laporan berkala dan laporan akhir yang diajukan oleh Kepala Desa kepada Bupati untuk BPKD yang telah diverifikasi dan mendapat rekomendasi pencairan dari BPMDK harus disertai dengan beberapa lampiran. Terkait dengan Proses pencairan di tempat yang terpisah untuk mendapatkan tahap pertama masuk tahap kedua, untuk pencairan tahap kedua masuk ketahap pertama. tapi pelaporannya harus tetap di masukkan sebagai admistrasi keuangan tapi kepala kampung belum memahami prosedur dengan baik laporan Alokasi Dana Desa (ADD) dibuat tersendiri, karena APBdes itu di APBdeskan tercover semua sumber dana, A Alokasi Dana Desa (ADD), Dana Desa, Bagi Hasil Pajak terkafer semua di APBDES berapa jumlah pendapatanta 1 tahun. Nanti pelaporanya ada di bilang realisasi Alokasi Dana Desa (ADD), ada juga Dana Desa tersendiri artinya kurang akomodir.

Dari hasil kesimpulan dalam pengamatan ini simpulkan bahwa dalam proses pelaporan dalam pengelolaan Aloksi Dana Desa (ADD) oleh kepala desa amuma ke BPMDK Kabupaten Yahukimo masih belum sesuai dengan peraturan yang telah ditetapkan dimana pemerintah Desa belum mampu untuk melaporkan kegiatan sesuai dengan jadwal waktu yang ditentukan terlihat dari keterlibatan Pendamping desa menjadi persoalan utama yang telah dirampungkannya dalam laporan realisasi setiap tahap.

\section{e. Pertanggungjawaban}

Pertanggungjawaban Alokasi Dana Desa (ADD) terintegrasi dengan Pertanggungjawaban APBDesa, sehingga pertanggung jawaban tersebut adalah Pertanggungjawaban APBdesa. Pertanggungjawaban tersebut dibuat dalam bentuk Laporan Penyelenggaraan Kepala Desa (LPKD) setiap akhir tahun dan bentuk susunan laporan penyelenggaraan kepala Desa mengacu pada PP 8/2016 tentang Perubahan Kedua atas PP 60/2014 tentang Dana Desa yang bersumber dari APBN.

Pembuatan Laporan Pertanggungjawaban yang dilakukan Pemerintah Desa khususnya Sekertaris Desa memilih menggunakan jasa pihak ketiga, karena Sekertaris Desa Amuma tergolong Sekertaris belum memiliki pengetahuan dan belum mengetahui proses pembuatan LPPD. Pihak ketiga yang dimaksud di Desa Amuma adalah Pendamping Desa menjadi peran utama dalam pembuatan laporan pertanggungjawaban.

Dalam Pembuatan Laporan PertanggungJawaban biasanya kami lebih memilih 
menggunakan jasa pihak ketiga, jadi karena belum mampu membuat biasanya kami menyewa Jasa, karena kami sempat mengajukan pelatihan kepada BPMDK tapi di tolak. Karena Sebelumnya saya kerja di kantor pertanian jadi belum ada pengalaman,apalagi petunjuk teknis pengelolaan Alokasi Dana Desa (ADD) berubah setiap tahunya. Untuk tahun 2017 akan berubah lagi. Dalam LPPD biasanya meminta bantuan kepada Sekdes yang lama karena sekdes yang lama lebih mengetahaui hal tersebut.

Adapun teknis pembuatan laporan pertanggungjawaban telah diatur dalam peraturan tentang petunjuk teknis alokasi dana desa dan peraturan tentang pengelolaan keuangan desa telah membagikan pedoman petunjuk teknis Alokasi Dana Desa (ADD) ke setiap desa yang ada di kabupaten yahukimo di dalamnya sudah terdapat format pelaporan dan format lainnya.

Sesuai dengan PP 8/2016 tentang perubahan kedua atas PP 60/2014 tentang dana desa yang bersumber dari APBN. Selain itu, realitas yang terjadi di desa amuma bahwa pembuatan laporan pertanggungjawaban tergolong lambat dan buruhburuh sifatnya yang penting dananya cair. Hal ini dikarenakan Sekretaris digantikan oleh pendamping desa terhadap tugas tersebut. Akibatnya, pembuatan laporan ini masih menunggu kesempatan dan waktu dari pendamping reaksi bersama kepala kampung untuk pertanggung jawabanya harusnya ada, dan laporan pertanggungjawaban belum pernah dibuat dan kami hanya ikuti petunjuk intruksi kepala kampung dalam setiap pengeluaran keuangan desa, bendahara desa wajib menyimpan bukti yang berupa nota pembelanjaan, karena dalam laporan pertanggungjawaban harus di sertai dengan nota. Setiap melakukan pengambilan barang di toko harus disertai dengan nota sebagai bukti pembelanjaan yang akan dilampirkan pada saat membuat pertanggung jawaban nantinya.

Pembuatan pelaporan pertanggungjawaban ini dimaksudkan agar setiap kegiatan yang dilakukan oleh kepala desa berdasarkan aturan yang ditetapkan dan tidak menyimpang. Hal ini pun merupakan wujud transparansi kepala desa kepada masyarakat. Namun, realitas yang terjadi di desa amuma di distrik amuma bahwa kegiatan laporan pertanggungjawaban tidak direncanakan dan dilaksanakan dengan baik dan memanfaatkan oleh pendamping desa. Hal ini terlihat dengan jelas bahwa penggunaan dana desa yang menjadi kendala di distrik amuma baik dalam pembuatan laporan pertanggungjawaban yang dilakukan.
3. Faktor-Faktor Yang Mempengaruhi Pengelolaan Alokasi Dana Desa Terhadap Percepatan Pembangunan Kampung Amuma Distrik Amuma Kabupaten Yahukimo

Adapun ada beberapa faktor yang mempengaruhi pengelolaan Alokasi Dana Desa (ADD) di Desa Amuma, adalah sebagai berikut:

a. Sumber Daya Manusia

Sumberdaya manusia Pemerintahan adalah bahwa segala potensi sumber daya yang dimiliki manusia yang dapat dimanfaatkan sebagai usaha untuk meraih keberhasilan dalam mencapai tujuan baik secara pribadi individu maupun di dalam instansi. Sumber daya tersebut meliputi tenaga dan kemampuan manusia (baik daya pikir serta daya fisiknya) benar-benar dapat dimanfaatkan secara terpadu dan secara optimal.

Sumber Daya Manusia sebagai faktor pertama dan utama dalam proses pembangunan dan pencapaian tujuan Pemerintahan. Apabila di dalam Pemerintah Desa sudah memiliki modal besar, teknologi canggih, sumber daya alam melimpah namun tidak ada sumber daya manusia yang dapat mengelola dan memanfatkannya maka tidak akan mungkin dapat meraih keberhasilan. Oleh sebab itulah pentingnya peran sumber daya manusia dalam Pemerintah Desa itu sangat diperlukan sebagai unsur utama dan unsur pengendali keberhasilan Pemerintah Desa.

Sumber daya manusia dalam pengelolaan ADD meliputi Tim Pelaksana Kegiatan, Tim Pendamping desa dan pemerintah Kabupaten Yahukimo. Adapun tugas Tim pelaksana kegiatan tingkat Desa adalah menyusun rencana daftar kegiatan bersama pemerintah Desa, menyusun daftar rencana kegiatan beserta rencana anggaran biaya dan Tim Pelaksana Kegiatan bertanggungjawab kepada Kepala Desa sebagai Penanggungjawab dan Pemegang Kekuasaan Pengelolaan Keuangan Desa.

Sementara itu tugas Tim Pendamping desa adalah memfasilitasi bimbingan teknis perencanaan kepada Tim Pelaksana Tingkat Desa, memberikan bimbingan dan asistensi penyusunan pengelolaan dan pemanfaatan Alokasi Dana Desa kepada Pelaksana Tingkat Desa dan melakukan fasilitasi pemecahan masalah berdasarkan pengaduan masyarakat serta pihak lainya dan melaporkan kepada Tim Fasilitasi Tingkat Kabupaten, dan tugas pemerintah adalah melakukan pembinaan terhadap Pemerintah Desa.

Dalam pengelolaan ADD, secara keseluruhan kinerja aparat Pemerintah Desa di Desa Amuma di Distrik Amuma kurang baik. Hal ini terlihat dengan proses pengelolaan yang tidak sesuai jadwal. Terhambatnya proses pengelolaan ADD kebanyakan diakibatkan oleh kualitas sumber daya manusia sebagai penggerak. Aparat pemerintah 
Desa di Desa Amuma rata-rata belum berpendidikan menyebabkan kurangnya pengetahuan tentang pengelolaan ADD, jenjang pendidikan aparat Pemerintah Desa di Desa Amuma .

\section{b. Kebijakan Kepala Kampung}

Kebijakan Kepala desa selalu menjadi otoriter tidak terima masukan dari masyarakat umum dan belum siap untuk diberikan wewenang pelaksanaan dana desa secara mandiri dan bertanggungjawab atas wewenang pengelolaan dana desa tahun 2016-2019.

Pelaksana penanggungjawab kegiatan masih belum bisa tepat waktu dalam menjalankan tugasnya seperti mengumpulkan bukti yang sah berupa nota pembayaran laporan penggunaan anggaran dan foto-foto kegiatan dalam perencanaan pembangunan kampung Amuma Distrik Amuma Kabupaten Yahukimo. Transparansi pada pengelolaan dana desa terhadap percepatan pembangunan kampung amuma masih rendah dalam pengawasan pengelolaan dana desa 2016-2019 hanya bisa diakses oleh BPK.

Pembagian dana desa yang sulit karena alasan keterbatasan dana di kampung Amuma. Sehingga sulitnya untuk berkomitmen melakukan pembangunan secara adil dan merata. Pemanfaatan Ilmu pengetahuan dan teknologi (IPTEK) yang belum maksimal pada sistem pertanggungjawaban kampung dalam memenuhi SPJ tepat waktu. Karena yang dikerjakan adalah pendamping desa.

\section{c. Penggunaan Dana Desa}

Dari data yang dihimpun penulis diketahui bahwa penggunaan dana desa di Distrik Amuma ini digunakan untuk bidang penyelenggaraan pemerintah seperti; Belanja Pegawai, Operasional Perkantoran, Operasional LPM, Operasional BPD, Musrembang yang setiap desa memiliki kesamaan dalam bidang penyelenggaraan pemerintah, untuk yang lainnya sesuai dengan rencana yang akan diselengarakan oleh masing-masing desa.

Bidang Pembangunan Desa di Distrik Amuma Kabupaten Yahukimo selalu prioritaskan perbaikan pembangunan jalan, pembangunan jalan raya dan pakar ternak dikarenakan masih banyaknya jalan yang rusak, itu pun pembangunan desa tidak sampai $55 \%$ dalam pembangunan desa tidak ada desa yang membangun jembatan, pembangunan siring, dan pembangunan sumur bor. Karena mata air langsung di konsumsi oleh masyarakat di kampung masing-masing dari 13 kampung tersebut.

Bidang Pembinaan Masyarakat seperti pembinaan Kamtibnas, pembinaan kegiatan karang taruna, sanggar seni, sosialisasi yang berbeda-beda di setiap desa, penyelenggaraan TPA, hari besar agama, pengembangan olah raga, fertival pameran desa, pertanian, promosi produk unggul, pembinaan ketertiban, pembinaan pekarangan rumah, pembinaan lainnya. Bidang sangat terbatas dan belum sama sekali dilakukan dan programnya belum terealisasi.

Bidang Pemberdayaan Masyarakat seperti, pelatihan perangkat desa, pelatihan BPD, Kegiatan PKK, pengelolaan posyandu, pengelolaan Paud, pengelolaan puskesmas induk, pelayanan $\mathrm{KB}$, Perpustakaan desa, musrembang, lomba desa, sanggar budaya dan lainnya. Terkait proses perencanaan dana desa dalam meningkatkan pembangunan di Desa Amuma, Pemerintah Desa terlebih dahulu menyusun tim pelaksanaan yang terdiri dari kepala desa selaku penanggung jawab operasional kegiatan (PJOK), sekretaris desa selaku penanggung jawab administrasi kegiatan (PJAK), kepala urusan keuangan selaku bendahara desa dan di bantu oleh lembaga kemasyarakatan di desa. Selanjutnya, proses pengelolaan Alokasi Dana Desa (ADD) terdiri dari tahapan perencanaan, pelaksanaan pengelolaan, dan tahap pelaporan dan pertanggungjawaban.

\section{d. Komunikasi}

Komunikasi adalah suatu proses penyampaian informasi (pesan, ide, gagasan) dari satu pihak kepada pihak lain. Komunikasi sangat penting dalam kehidupan manusia sebab komunikasi merupakan sebuah proses untuk menyampaikan maksud atau pesan yang menjadi tujuan kepada orang lain. Sehingga, jika manusia ingin menyampaikan apa yang ia maksudkan, ia harus berkomunikasi. begitu pula sebaliknya kita bisa memahami seseorang dengan melalui komunikasi. Namun realitas yang terjadi di Desa Amuma komunikasi merupakan faktor penghambat dalam melaksanakan pengelolaan Alokasi Dana Desa (ADD), komunikasi masyarakat yang kurang mampu mengutarakan pendapat di depan umum sehingga Kepala Desa Amuma mengalami keangguhan dalam menetukan program yang ingin di laksanakan.

Berdasarkan hasil penelitian yang dilakukan penulis masyarakat kurang mampu mengeluarkan pendapat di depan umum. Masyarakat sangat antusias pada saat akan diadakan Musrenbang Desa tapi pada saat Musrenbang Desa berlangsung masyarakat tidak terlalu aktif, sehingga kepala Desa mempunyai kendala dalam menentukan program yang ingin di jalankan, biasanya nanti setelah Musrenbang Desa banyak masyarakat yang agak protes dan bernada kontra terhadap hasil yang telah di tentukan. Sejalan dengan pendapat diatas, salah satu masyarakat yang berasal dari kampung huewik juga mengatakan hal yang serupa, bahwa memang kebanyakan masyarakat amuma pada saat Musrenbang desa tidak terlalu aktif dalam forum, tetapi kalau diluar forum masyarakat tersebut aktif membicarakan program yang akan dilaksanakan. Kita tidak terbiasa bicara di depan umum kebanyakan masyarakat malu mengungkapkan pendapatnya. 
Berbicara di depan umum merupakan salah satu teknik atau seni berbicara yang harus dimiliki pembicara maupun peserta rapat untuk mampu menciptakan suasana rapat yang mempunyai feedback, sebab jika peserta rapat kebanyakan diam, maka forum MusrenbangDesa yang dilaksanakn oleh Aparat kepala Desa Amuma hanya berlangsung satu arah sehingga aparat pemerintah Desa Amuma mempunyai kebijakan yang selalu salah san kesulitan untuk mengetahui keinginan masyarakat.

\section{Pembahasan}

Hasil penelitian menunjukan bahwa tahapan perencanaan pengelolaan dana desa dalam meningkatkan percepatan pembangunan desa masih kurang efektif dimana dilakukan dengan melihat proses musrembang desa untuk membahas rencana kegiatan penggunaan anggaran APBDes serta bagaimana proses pengelolaan APBDes, dimana dalam tahapan perencanaan ini diukur dengan jumlah pihak yang berpartisipasi dalam proses musrembang desa. Selain itu, dalam tahapan perencanaan pengelolaan dana desa menunjukan bahwa masih kurangnya partisipasi masyarakat dalam mengikuti setiap tahapan proses pengelolaan dana desa, serta dalam proses musrembang pada tahapan perencanaan ini kurangnya transparansi informasi dari pemerintah desa yang berdampak pada rendahnya tingkat partisipasi dan pengawasan dari masyarakat desa baik secara lembaga maupun individu dalam setiap proses pengelolaan dana desa.

Pada tahapan pelaksanaan dana desa amuma distrik amuma kabupaten Yahukimo ini penggunaannya sudah terfokus pada pembangunan desa yaitu pada perbaikan jalan rusak yang sudah di perbaiki melalui pembangunan jalan swadaya masyarakat. Namun pembangunan yang telah dilaksanakan hanya satu desa yang sudah mencapai $50 \%$ yaitu Amuma dengan persentase $51,92 \%$, dilihat dari hasil penggunaan anggaran pada kas umum desa amuma.

Pengelolaan dana desa sudah di tetapkan untuk memenuhi empat bidang, maka dari itu untuk bidang pembangunan sudah memiliki persentase yang lebih rendah dari tiga bidang lainnya, walaupun tidak mencapai 55\% dalam bidang pembangunan itu dikarenakan keterbatasan dana yang ada sehingga dana keseluruhan tidak dapat dipakai untuk pembangunan desa saja, selain terkendala kerena dana yang kurang memadai, dana juga di fokuskan untuk penyelenggaraan pemerintah desa sebesar Rp.220.000.000-Rp.299.580.000. Selanjutnya Pembinaan kemasyarakatan merupakan salah satu program pemerintah dalam meningkatkan serta mengelola lembaga dan sumber daya manusia agar lebih baik dan bekerja sesuai dengan harapan. Pembinaan kemasyarakat dapat dilakukan dengan berbagai cara baik melalui pelatihan, rapat, lomba, peringatan hari besar dan lain-lain. Pembinaan kemasyarakatan Amuma di Desa Distrik Amuma Kabupaten Yahukimo sudah terlaksana dengan pencapaian sekitar 4\%-10\%. Dengan uraian Desa Amuma.
Pemberdayaan masyarakat desa adalah upaya untuk mengembangkan kemandirian dan kesejahteraan masyarakat dengan meningkatkan pengetahuan, sikap, keterampilan, perilaku, kemampuan, kesadaran, serta memanfaatkan sumber daya melalui penetapan kebijakan, program, kegiatan, dan pendampingan yang sesuai dengan esensi masalah dan prioritas kebutuhan masyarakat desa. Pemberdayaan kemasyarakatan Desa Kampung Amuma Distrik Amuma Kabupaten Yahukimo sudah terlaksana dengan pencapaian sekitar $8 \%-15 \%$ persen.

Dengan demikian tahapan pelaksanaan Pengelolaan Dana Desa dalam meningkatkan perencanaan pembangunan kampung Amuma Distrik Kabupaten Yahukimo berjalan dengan baik, akan tetapi walaupun proses pembangunan berjalan dengan baik namun, tahapan pelaksaan ini harus melibatkan masyarakat sebagai tim evaluasi atau tim pengawas dari setiap kegiatan yang di adakan oleh pemerintah desa. Setiap jajaran anggota perangkat desa memiliki tanggungjawab sesuai dengan visi dan misi desa tersebut. Pertanggungjawaban itu berupa pelaksanaan pengelolaan dana yang dilakukan harus sesuai dengan anggaran yang telah ditentukan dan dapat ditunjukkan hasilnya.

Pada tahapan pertanggungjawaban dalam proses Pengelolaan Dana Desa dalam meningkatkan perencanaan pembangunan kampung Amuma Distrik Kabupaten Yahukimo sudah cukup efektif walaupun adanya keterlambatan dalam mengumpulkan hasil laporan pertanggungjawaban, dimana penyusunan laporan pertanggungjawaban sudah disusun sendiri oleh pemerintah Desa serta adanya evaluasi kegiatan yang seharusnya dilakukan bersama masyarakat.

Hal ini karena proses yang tercipta dalam setiap tahapan Pengelolaan Dana Desa tersebut sudah sesuai dengan prinsip pengelolaan dan tujuan Dana Desa yang mengutamakan transparansi informasi kepada masyarakat sebagai tim evaluasi dari setiap kegiatan pembangunan yang dilakukan. Jika dilihat dari pelaksanaan pengelolaan dana desa amuma distrik Amuma tujuan dan fungsi program alokasi dana desa belum tersentuh secara menyeluruh, dari tujuan alokasi dana desa yang baru dapat dirasakan masyarakat yaitu pembangunan rumah, jalan dan peningkatan pengamalan nilai-nilai keagamaan sosial, bidang kesehatan, dan terlihat pula dari program ibu PKK dan lain-lain belum diperdayakan, dan penyelenggaraan pemerintah seperti belanja alat kantor desa, renovasi kantor desa dan lain-lain.

Dari penjelasan diatas, terlihat bahwa tujuan dari program alokasi dana desa ini dapat dikatakan tercapai yaitu peningkatan pembangunan, pertanian dan perikanan. Sedangkan dalam peningkatan pendapatan belum tercapai karena aparatur desa dalam bidang pemberdayaan masyarakat belum memperioritaskan kegiatan ekonomi kreatif sebagai salah satu program alokasi dana desa.

Berdasarkan uraian dari tahapan perencanaan, tahap pelaksanaan pengelolaan dan tahap pertanggungjawaban seharusnya terdapat monitoring yang dilakukan untuk melihat hasil dari kegiatan yang dilakukan, seharusnya pembangunan tidak berfokus pada 
pembangunan fisik saja berupa pembangunan jalan, namun seharusnya membesarkan pada bidang penyelenggaraan pemerintah yang langsung menyentuh masyarakatnya. Karena pemberdayaan masyarakat dapat memacu peningkatan ekonomi masyarakat yang dapat berkembang dan maju bila diberdayakan dengan tepat.

Berdasarkan penjelasan di atas maka dapat pula mengukur peran dana desa dalam perencanaan pembangunan kampung Amuma Distrik Amuma Kabupaten Yahukimo dapat dilihat dari kesejahteraan masyarakat. Kesejahteraan masyarakat adalah suatu keadaan terpenuhi kebutuhan dasar masyarakat baik melalui program-program yang diadakan pemerintah, maupun kebutuhan dasar yang telah terpenuhi oleh usahausaha yang diakukan masyarakat.

Kesejahteraan masyarakat dapat diukur melalui berbagai indikator, indikator kesejahteraan merupakan suatu ukuran ketercapaian masyarakat dimana masyarakat dapat dikatakan sejahtera atau tidak sebagai indikatorindikatornya yaitu tingkat pendidikan, tingkat kesehatan, tingkat pendapatan masyarakat, komposisi pengeluaran masyarakat, dan tingkat perumahan masyarakat yang menjadi tolak ukur kesejahteraan masyarakat karena program Alokasi Dana Desa, maka berdsarkan hal tersebut data-data yang diperoleh sebagai berikut:

1. Tingkat Pendidikan

Pendidikan merupakan bimbingan atau pertolongan yang diberikan oleh orang dewasa kepada perkembangan anak untuk mencapai kedewasaan dengan tujuan agar anak cakap melaksanakan tugas hidupnya sendiri. perencanaan pembangunan kampung Amuma Distrik Amuma Kabupaten Yahukimo jika ditinjau dari latar belakang pendidikan sudah menerapkan wajib belajar sembilan tahun.

Dampak dari penyelenggaraan dana desa di bidang pendidikan belum dapat dirasakan langsung oleh masyarakat Kecamatan Natar ini dikarenakan pengalokasian dana tersebut belum dialokasikan ke bidang pendidikan. Sekalipun dari program dana desa belum dapat dirasakan langsung oleh masyarakat tetapi tidak menjadikan masyarakat putus sekolah dikarenakan banyaknya sekolah terdekat yang dapat dijangkau oleh masyarakat dan adanya biaya pendidikan dikenal tidak mahal karena mendapat bantuan dari pemerintah Kabupaten Yahukimo.

2. Tingkat Kesehatan

Kesehatan adalah suatu keadaan sejahtera dari badan, jiwa, dan sosial yang memungkinkan setiap orang hidup produktif secara ekonomis. Dari program dana desa untuk kesehatan masyarakat sudah adanya sosialisasi, sosialisasi bahaya narkoba, simultan jamban keluarga, pengelolaan posyandu, pengelolaan poskesdes, tersebut tentu saja dapat meningkatkan pelayanan kesehatan masyarakat menjadi perihatin dan petugas belum ada dilapngan. Tetapi, penulis melihat bahwa dengan sarana kesehatan yang ada di masyarakat dalam penanganan ibu melahirkan sudah tidak menggunakan perawat pun tetapi diandalkan Tuhan. sehingga angka kematian bayi dan ibu melahirkan tidak ada, serta masyarakat memiliki gangguan kesehatan lebih memilih jalan Tuhan.

3. Tingkat Pendapatan

Tingkat pendapatan merupakan penghasilan yang diperoleh masyarakat yang berasal dari pendapatan kepala rumah tangga. Penghasilan tersebut biasanya dialokasikan untuk konsumsi, kesehatan maupun pendidikan dan kebutuhan lainnya yang bersifat material.

Menurut SKPMP 2015 tingkat pendapatan perbulan dikatakan sejahtera adalah lebih dari Rp.500.000 Adanya program alokasi dana desa ini tidak memberikan dampak positif terhadap pendapatan masyarakat, ini dikarenakan pengelolaan alokasi dana tidak memiliki program pemberdayaan ekonomi masyarakat. Seharusnya dari program alokasi dana desa tersebut digunakan untuk pelatihan-pelatihan kewirausahaan dan pembuatan industri rumah tangga kreatif untuk meningkatkan ekonomi masyarakat.

4. Komposisi Pengeluaraan

Pola konsumsi rumah tangga merupakan salah satu indikator kesejahteraan rumah tangga/keluarga. Makin tinggi tingkat penghasilan rumah tangga, maka makin kecil proporsi pengeluaran untuk makan terhadap seluruh pengeluaran rumah tangga. Dapat dikatakan bahwa rumah tangga/keluarga akan semakin sejahtera bila persentase pengeluaran untuk makan akan jauh lebih kecil di bandingkan persentase pengeluaran untuk non makanan atau $<80 \%$ dari pendapatan.

Meskipun tingkat pendapatan masyarakat tidak menentu, tidak membuat masyarakat memperkecil atau menambah pengeluaran. Jika pendapatan mereka tinggi maka konsumsi dapat tercukupi dengan baik, akan tetapi jika pendapatan mereka sedikit maka kebutuhan makan saja. Umumnya pengeluaran untuk konsumsi berkisar Rp.20.000. ini belum termasuk biaya pendidikan, kesehatan, perumahan serta pajak bumi dan bangunan, kendaraan bermotor dan lainnya. Hanya selalu menghasilkan hasil kebun dan buah-buahan keladi dan lainnya.

Karena program alokasi dana desa ini belum menyentuh ekonomi kreatif masyarakat amuma. sehingga alokasi dana desa ini belum dapat meningkatkan pendapatan masyarakat secara keseluruhan, karena ini tidak berpengaruh terhadap pendapatan masyarakat maka otomatis tidak akan berpengaruh juga terhadap komposisi pengeluaran masyarakat.

5. Tingkat Insfrastruktur Masyarakat

Menurut Biro Pusat Statistik (BPS) dikatakan perumahan yang dianggap sejahtera adalah tempat berlindung yang mempunyai dinding, lantai dan atap yang baik. Bangunan yang dianggap kategori sejahtera adalah luas lantainya lebih dari $10 \mathrm{~m} 2$ dan bagian terluas dari rumah bukan tanah, status penguasaan tempat tinggal milik sendiri. Bentuk bangunan rumah masyarakat $65 \%$ permanen, $25 \%$ semi permanen dan 
$10 \%$ adalah non permanen. Tetapi, masyarakat Kampung Amuma Distrik Amuma Kabupaten Yahkimo tidak seperti yang disampaikan oleh BPS karena masyarakat masih ttinggal di rumah tidak layak di huni.

Kondisi air bersih juga sudah dikatakan baik. Dan untuk penerangan listrik tidak ada di kampung amuma hanya solares di rumah kepala desa. Apabila dilihat dari indikator perumahan, warga sudah dapat dikatakan tidak sejahtera karena tidak memenuhi ketegori sejahtera. Beberapa indikator kesejahteraan masyarakat sudah dijelaskan diatas, telah menunjukan bahwa alokasi dana desa berdampak negatif pada masyarakat sekitas, seperti masyarakat tidak harus ke sungai karena sudah baiknya.

\section{Kesimpulan}

1. Pengelolaan Dana Desa Terhadap Percepatan Pembangunan Kampung Amuma Distrik Amuma Kabupaten Yahukimo.

Pengelolaan dana desa dalam meningkatkan percepatan pembangunan kampung amuma distrik amuma dimana dalam proses pengelolaan dana desa ada tiga tahap yakni perencanaan, pelaksanaan, pelaporan dan pertanggungjawaban. Berdasarkan hasil penelitian, tahapan pelaksanaan pengelolaan dana desa dalam meningkatkan percepatan pembangunan desa belum cukup efektif dimana dana yang dianggarkan untuk percepatan pembangunan tidak lebih besar daripada tiga bidang lainnya. Bidang pembangunan desa tidak lebih besar anggaran maupun persentasenya dibanding dengan bidang penyelenggaraan pemerintah, pembinaan masyarakat, pemberdayaan masyarakat. Jumlah pengelolaan alokasi dana desa Amuma Distrik Amuma Kabupaten Yahukimo mendapat besaran dana berkisar pada tahun $2016 \mathrm{Rp}$ 623.671.035, tahun $2017 \mathrm{Rp}$ 549.266.883, tahun 2018 Rp 752.110.000 dan tahun 2019 Rp 830.662.000. Pada tahapan pertanggungjawaban dalam proses Pengelolaan Dana Desa dalam meningkatkan Pembangunan Kampung Amuma Distrik Amuma Kabupaten Yahukimo sudah cukup efektif walaupun adanya keterlambatan dalam mengumpulkan hasil laporan pertanggungjawaban, dimana penyusunan laporan pertanggungjawaban sudah disusun sendiri oleh pemerintah Desa serta adanya evaluasi kegiatan yang seharusnya dilakukan bersama masyarakat.

2. Faktor-faktor Penghambat Pengelolaan Dana Desa terhadap Percepatan Pembangunan Kampung Amuma Distrik Amuma Kabupaten Yahukimo adalah sebagai berikut:

\section{a. Sumber Daya Manusia (SDM)}

Sumber Daya Manusia sebagai faktor pertama dan utama dalam proses pembangunan dan pencapaian tujuan Pemerintahan. Apabila di dalam Pemerintah Desa sudah memiliki modal besar, teknologi canggih, sumber daya alam melimpah namun tidak ada sumber daya manusia yang dapat mengelola dan memanfatkannya maka tidak akan mungkin dapat meraih keberhasilan. Oleh sebab itulah pentingnya peran sumber daya manusia dalam Pemerintah Desa itu sangat diperlukan sebagai unsur utama dan unsur pengendali keberhasilan Pemerintah Desa. Secara khusus Kepala desa belum siap untuk diberikan wewenang pelaksanaan dana desa secara mandiri dan bertanggungjawab atas wewenang pengelolaan dana desa tahun 2016-2019.

b. Kebijakan Kepala Kampung

Kebijakan Kepala desa selalu menjadi otoriter tidak terima masukan dari masyarakat umum dan belum siap untuk diberikan wewenang pelaksanaan dana desa secara mandiri dan bertanggungjawab atas wewenang pengelolaan dana desa tahun 2016-2019. Dan pelaksana penanggungjawab kegiatan masih belum bisa tepat waktu dalam menjalankan tugasnya seperti mengumpulkan bukti yang sah berupa nota pembayaran laporan penggunaan anggaran dan fotofoto kegiatan dalam perencanaan pembangunan kampung Amuma Distrik Amuma Kabupaten Yahukimo. Pembagian dana desa yang sulit karena alasan keterbatasan dana di kampung Amuma. Sehingga sulitnya untuk berkomitmen melakukan pembangunan secara adil dan merata.

c. Penggunaan Dana Desa Belum Sasaran

Penggunaan dana desa belum menyentuh di masyarakat Amuma dari pelaksanaan dana desa secara mandiri, justru penggunaan dana desa ini digunakan untuk bidang penyelenggaraan pemerintah seperti; Belanja Pegawai, Operasional Perkantoran, Operasional LPM, Operasional BPD, Musrembang yang setiap desa memiliki kesamaan dalam bidang penyelenggaraan pemerintah, untuk yang lainnya sesuai dengan rencana yang akan diselengarakan oleh masing-masing desa.

\section{d. Komunikasi Yang Kurang Terhadap Masyarakat}

Komunikasi sangat penting dalam kehidupan manusia sebab komunikasi merupakan sebuah proses untuk menyampaikan maksud atau pesan yang menjadi tujuan kepada orang lain. Sehingga, jika manusia ingin menyampaikan apa yang ia maksudkan, ia harus berkomunikasi. begitu pula sebaliknya kita bisa memahami seseorang dengan melalui komunikasi. Namun realitas yang terjadi di Desa Amuma komunikasi merupakan faktor penghambat dalam melaksanakan pengelolaan Alokasi Dana Desa (ADD), komunikasi masyarakat yang kurang mampu mengutarakan pendapat di depan umum sehingga Kepala Desa Amuma mengalami keangguhan dalam menetukan program yang ingin di laksanakan.

\section{Daftar Pustaka}

Astrella Janice, (2015) Studi Tentang Pelaksanaan Tugas Dan Fungsi Badan Pemberdayaan 
Masyarakat Desa (Bpmd) Dalam pembangunan Desa Di Desa Tanjung Lapang Kecamatan Malinau Barat Kabupaten Malinau, Ejournal Ilmu Pemerintahan, Volume 3, Nomor 3.

Arikunto, Suharsimi, (2002) Prosedur Penelitian: Suatu Pendekatan Praktek. Jakarta: Rineka Cipta

Ahmadi dan Cholid Nuroboko, (2001) Metode Penelitian, Jakarta: PT. Bumi Aksara.

Abizar, (1988) Komunikasi Organisasi dan Mengatasi Masalah Manusia Di Dalam Organisasi, Alih Bahasa.Jakarta: Depdikbud Dikjen Dikti Cipta.

Arifin P. Soeria Atmadja, (2009) Keuangan Publik Dalm Perspektif Hukum, Jakarta: Rajawali Pers, Ed.

Badrudin Rudy, (2012) Ekonomika Ekonomi Daerah, UPP Stim YKPN, Yogyakarta.

Chabib Soleh, Heru Rocmansjah, (2014) Pengelolaan Keuangan Desa, Bandung, Fokus Media.

Creswell, dan Locke, Spriduso \& Silferman. Patton, (19941987) Dalam Bukunya: Kualitatif, Dengan Metode Analisis Deskriptif, Mengemukakan Bahwa Qualitative.

Hassan Shadily (1993), Sosiologi Untuk Masyarakat Indonesia, Jakarta: Rineka Cipta.

H.A.W.Widjaja, (2007) Penyelenggaraan Otonomi Daerah di Indonesia, PT.Raja Grafindo Persada, Jakarta.

Ivancevich John M, 2002, Perilaku Dan Manajemen Organisasi 7, Erlangga, Jakarta. Cipta.

Kansil dan Cristine, (2002) Pemerintahan Daerah di Indonesia, Hukum Administrasi Daerah, Sinar Grafika Jakarta.

Kalimandhanu, (2014) Studi Tentang Pengelolaan Alokasi Dana Desa Di Desa Perangat Selatan Kecamatan Marang Kayu Kabupaten Kutai Kartanegara, eJournal Ilmu Pemerintahan, Volume Nomor, 2008-2022.

Kartasasmita, Ginandjar, (2001) Pembangunan Untuk Rakyat: Memadukan. Pertumbuhan Dan Pemerataan, Jakarta : Pustaka CIDESINDO

Kalalo Riken, Ronny Gosal, Josef Kairupan, (2017) Peranan Badan Permusyawaratan Desa Dalam Menjaring Aspirasi Masyarakat Untuk Menetapkan Skala Prioritas Pembangunan (Studi Di Desa Lompad Kec. Ranoyapo Kab. Minahasa Selatan).

Koentjaraningrat (2002), Pengantar Ilmu Antropologi, Jakarta: Rineka Cipta.

Lofland dan Lofland, dalam Moleong, Lexy (2011) Metodologi Penelitian Kualitatif Edisi Revisi. Bandung. PT. Remaja Rosdakarya.

(2013) Metodologi Penelitian Kualitatif Edisi Revisi. Bandung. PT. Remaja Rosdakarya.

Milles \& Huberman dalam Sugiyono (2003). Teknik Pemeriksaan Keabsahan Data Baru Cipta.

M.Iqbal Hasan, (2002) Analisis Data dan Penelitian dengan Statistik, PT. Bumi Aksara, Jakarta.
Priyo Sambodo, (2014.) Implementasi Dana Bantuan PT. Kideco Jaya Agung Dalam Pembangunan Di Desa Sempulang Kecamatan Tanah Grogot Kabupaten Paser, Ejournal Ilmu Pemerintahan, Volume 2, Nomor 2.

Peraturan Menteri Dalam Negeri Nomor 37 Tahun 2007 Tentang Pedoman Pengelolaan Keuangan Desa.

Peraturan Daerah Kabupaten Kepulauan Meranti Nomor 16 Tahun 2011, Pasal 1 Butir (12)

Peraturan Pemerintah No. 8 tahun 2016 tentang perubahan kedua atas PP Nomor 60 tahun 2014 tentang dana desa yang bersumber dari anggaran pendapatan dan belanja negara (APBN).

Peraturan Pemerintah RI Nomor 72 tahun 2005 tentang desa.

Peraturan Pemerintah No. 60 tahun 2014 tentang Dana Desa yang bersumber dari Anggaran Pendapatan dan Belanja Negara.

Permendagri No. 113 tahun 2014 tentang Pengelolaan Keuangan Desa. PMK No.93/PMK.07/2015 tentang tata cara Pengalokasian, Penyaluran, Penggunaan, Pemantauan dan Evaluasi Dana Desa.

Peraturan Menteri Desa, Pembangunan Daerah Tertinggal dan Transmigrasi No.5 tahun 2015 tentang Penetapan Prioritas Penggunaan Dana Desa tahun 2015 (diperbaharui tiap tahun).

Peraturan Menteri Keuangan Nomor 49 Tahun 2016 tentang cara pengelolaan, penyaluran, penggunaan, pemantauan, dan evaluasi Dana

Peraturan Menteri Dalam Negeri Nomer 43 Tahun 2014 Pedoman Pengelolaan Keuangan Desa Pasal 92 Ayat 2 Alokasi Dana Desa berasal dari APBD kabupaten/kota.

Raharjdo Adisasmita, (2011) Pembiayaan Pembangunan Daerah, Yogyakarta: Graha Ilmu.

Rozaki, Abdur dan Sg. Yulianto. (2015). Buku Saku Pelembagaan Demokrasi Melalui Musyawarah Desa. Yogyakarta: IRE-CCES.

Sugiyono (2004). Metode Penelitian Kualitatif dan Kuantitatf $R \& D$. Bandung: Cipta.

Sadono Sukirno, (1999) Ekonomi Pembangunan, Lembaga Penerbit Fakultas Ekonomi UI dan Bina Grafika Jakarta, Jakarta.

Supriadi, Edy. (2015). Pertanggungjawaban Kepala Desa Dalam Pengelolaan Keuangan Desa Berdasarkan Undang-Undang No. 6 Tahun 2014 Tentang Desa. Jurnal IUS.

Todaro, Michael P. (1998) Pembangunan Ekonomi Di Dunia Ketiga, Edisi. Keenam, Jakarta: Erlangga.

Tresiana, Novita. (2013) Metode Penelitian Kualitatif. Bandar Lampung: Lembaga Penelitian Universitas Lampung.

Undang-Undang Nomor 6 Tahun 2014 Tentang Desa, Pasal 72 ayat (1) point (d), dan butir (4), op.cit, h. 41. 
Undang-Undang No. 9 tahun 2015 tentang pemerintah daerah, dan pemerintah daerah menjalakan otonomi seluas-luasnya

Undang-Undang No. 6 tahun 2014 Pasal 72 Ayat 1 (d) dan Ayat 4 tentang desa menyatakan pemerintah mengamanatkan bahwa sumber pendapatan desa berasal dari bagian dana perimbangan keuangan pusat dan daerah yang diterima oleh kabupaten/kota.

Undang-Undang No 32/2004 maupun PP No 72/2005, terlihat sangat kentara adanya tarikan ke atas. Pasal 15 ayat (2) PP No. 72/2005 menyebutkan bahwa Kepala Desa mempunyai kewajiban untuk memberikan laporan penyelenggaraan Pemerintahan Desa kepada Bupati/Walikota.

Undang-Undang Republik Indonesia Nomor 32 Tahun 2004 Tentang Pemerintahan Daerah, pasal 10 ayat (3).

Undang-Undang Nomor 6 Tahun 2014 Tentang Desa, Pasal 67 ayat (2) point (b),(d) dan (e), op.cit, h. 3711 Ibid, h. 38 